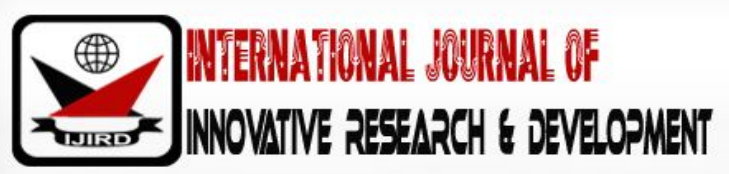

ISSN 2278 - 0211 (Online)

\section{Comparative Effect of Vernonia Amygdalina and Metformin in Alloxan Induced Diabetes Mellitus}

\author{
\begin{tabular}{|c|}
\hline Christian Onahinon \\
Co-Researcher, Department of Physiology, Benue State University, Nigeria \\
Dr. Julie Ibu \\
Chief Inspectors, National Youth Service Corps, Benue State Secretariat, Nigeria \\
Dr Nndunno Akwaras \\
Senior Registrar, Department of Physiology, Benue State University, Nigeria \\
Dr. Emmanuel Eru \\
Lecturer, Department of Physiology, Benue State University, Nigeria
\end{tabular}
}

Abstract:

Metformin is a biguanide and its mechanism of action is exhibited at extra pancreatic level. In clinical practice, it is the first line therapy recommended for newly diagnosed type 2 diabetes mellitus patient (ADA, 2014). Vernonia amygdalina (VA) is a common shrub consumed in Nigeria. This study was done to investigate the comparative effect of VA and metformin in alloxan induced hyperglycaemia in Wistar rats. Twenty five (25) adult Wistar albino rats of both sexes weighing 200-250g were randomly allocated into five (5) groups with 5 rats per group. Group 1 was given normal saline alone without inducing hyperglycaemia to serve as normoglycaemic control, while group 2,3, 4 and 5 were given $6.5 \mathrm{mg} / 100 \mathrm{~g}$ body weight of alloxan monohydrate to induce hyperglycaemia according to the method of Osikwe et al.,2015, Onahinon et al.,2018. After inducing hyperglycaemia, group 2 were given normal saline, group 3,10mg/100g body weight of VA, group $4,20 \mathrm{mg} / 100 \mathrm{~g}$ body weight of metformin and group 5,10mg/ $100 \mathrm{~g}$ body weight of VA and $20 \mathrm{mg} / 100 \mathrm{~g}$ body weight of metformin for a duration of 2 weeks. Results showed that the fasting blood glucose of group 1 was $81 \pm 2.6 \mathrm{mg} / \mathrm{dl}$. The fasting blood glucose of group 2 was $293 \pm 6.5$ vs $332 \pm 17.5 \mathrm{mg} / \mathrm{dl}$, group 3 was $304 \pm 3.8 \mathrm{vs} 198 \pm 7.4 \mathrm{mg} / \mathrm{dl}$, group 4 was $306 \pm 7.2 \mathrm{vs} 190 \pm 4.2 \mathrm{mg} / \mathrm{dl}$ and group 5 was $310 \pm 7.4$ vs $155 \pm 1.6 \mathrm{mg} / \mathrm{dl}$. There was significant difference in the basal fasting blood glucose and fasting blood glucose after group 2,3,4 and 5 were given alloxan $(p<0.01)$. There was significant difference between group 2 and group 3 , group 2 and group 4, and group 2 and group $5(\mathrm{p} \varangle 0.01$ ). There was no significant difference between group 3 given VA and group 4 given metformin alone $(p>0.05)$ however, the percentage change in fasting blood glucose in group 3 and 4 after agents were administered were $34.9 \%$ and $37.9 \%$ respectively. There was a significant difference between group 5 and group 3, and group 5 and group $4(\mathrm{p} \varangle 0.01)$. This result shows that the antihyperglycaemic effect of VA shows similar efficacy as that of metformin.

Keyword: Vernonia amygdalina, metformin, alloxan induced diabetes mellitus, fasting blood glucose

\section{Introduction}

Diabetes mellitus once described as a rare disease (Tattersall, 2009), is now one of the most common noncommunicable diseases globally (IDF, 2009). The term diabetes mellitus describes a metabolic disorder of multiple etiology characterized by chronic hyperglycaemia with disturbances of carbohydrate, fat and protein metabolism resulting from defects in insulin secretion, insulin action, or both (Kjems et al., 2001). Diabetes mellitus is increasingly seen as a disease in which multiple organs and tissues in the body play one or more roles in causing hyperglycaemia. These organs/tissues include muscle, fat cells, liver, the pancreas, intestine, kidney and the brain (Defronzo,2009). Due to the aetiopathogenesis of diabetes mellitus, harmful side effects of synthetic drugs, the inability of existing modern therapies to control all the pathological aspects of the diabetic disorder, enormous cost of modern drugs as well as the poor availability of the advanced therapies for many rural populations in developing countries (Tanaka et al., 1992), alternative strategies to current pharmacotherapy of diabetes mellitus are urgently needed. Presently, available therapies used for the management of diabetes include "insulin, insulin secretagogues (sulfonylureas, meglitinides), insulin sensitizers (biguanides, thiazolidinedione), agents that enhance incretin secretion and action (incretin analogues, incretin mimetics, dipeptidyl peptidase IV (DPP-IV) inhibitors). Other agents include those that decrease gastrointestinal glucose absorption (alpha glucosidase inhibitors, alpha amylase 
inhibitors, sodium-glucose co-transporter (SGLT-1) selective inhibitors), agents that promote renal glucose excretion (sodiumglucose co-transporter (SGLT-2) inhibitors) and many others such as amylin analogue, bile acid sequesterants and bromocriptine (Verspohl, 2012). With increasing quest for better therapy that is readily available and cost effective, there has been increasing demand for the use of plant products with better efficacy. Ethnobotanical and ethnopharmacological surveys report that more than 1200 plants are being used in many ethnic societies around the world in traditional medicine for their alleged hypoglycemic activity (Akah et al.,2002) and Vernonia amygdalina is one of them .

\section{Materials and Method}

Fresh leaves of V. amygdalina were collected from the natural habitat in Makurdi, Benue State, Nigeria. The leaves were confirmed by a taxonomist from the Department of Botany in the Faculty of Science, Benue State University and was allocated a voucher number and deposited in the herbarium of the department.

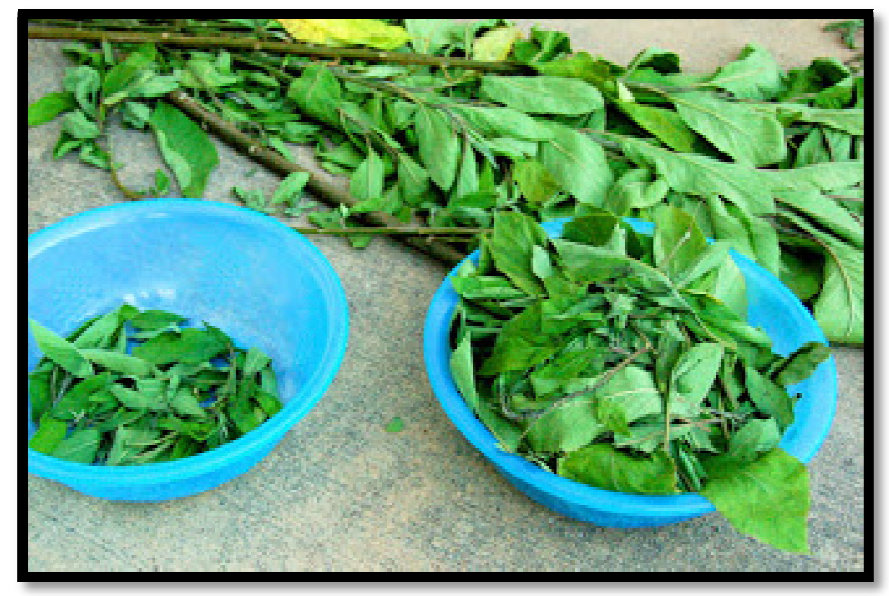

Figure 1: Leaves of Vernonia Amygdalina Used in the Study

\subsection{Preparation of Extract}

The leaves were sorted out to obtain only the fresh leaves and washed with distilled water without squeezing to remove debris and dust particles. They were shade dried for ten days and then, the dried leaves were pulverized with LG electric grinding machine. A portion, (600 g) of the powdered leaves were soaked in $2400 \mathrm{ml}$ of $70 \%$ ethanol for 72 hours with the solution thoroughly stirred twice daily. The extracts were then be filtered with WHATMAN no1 filter paper. The filtrate was air dried and then reconstituted with distill water later.

\subsection{Chemicals}

Alloxan monohydrate (Sigma, St Louis MO, USA) used to induce diabetes and Metformin with a brand name DIABETMIN (Hovid pharmaceutical Ltd)

\subsection{Animals}

Adult albino rats of Wister strain weighing 200-250g of either sex were purchased from the disease-free stock of the animal house of the College of Health Sciences, Benue State University, Makurdi and used for the study. They were maintained in normal and standard laboratory conditions of temperature $28^{\circ} \mathrm{C}$ and relative humidity (with 12-hour light dark cycle) and adequate ventilation. The animals were fed with commercial diet (Vital Feed Nig.Ltd.) and water ad libitum. Food was withheld 8 hours before the experiments, but they had free access to water. Permission for the use of animals and animal protocols were obtained from the Animal Ethics Committee of Benue State University Makurdi, prior to the experimentation.

\subsection{Animal Categorization}

The animals were allowed 14-day acclimatization period, after which they were randomly allocated into five groups of 5 rats per group: $(n=5)$

\subsection{Induction of Diabetes}

Diabetes was induced on group 2, 3, 4 and 5 by intraperitoneal injection of alloxan monohydrate $(6.5 \mathrm{mg} / 100 \mathrm{~g})$ in normal saline $(0.9 \% \mathrm{NaCl})$, Osikwe et al.,2015, Onahinon et al.,2018. 50\% glucose solution was given to prevent initial hypoglycaemia caused by alloxan. Diabetes was confirmed three days later in alloxan- induced animals showing fasting blood sugar (FBS) level $\geq 126 \mathrm{mg} / \mathrm{dl}$ by using glucometer to monitor the blood sample from the tail vein. 


\section{Animal Grouping and Experimental Design}

The animals were randomly allocated into five (5) groups of 5 animals per group $(n=5)$

- Group1: non diabetic control given normal saline

\subsection{ALLOXAN Induced}

- Group 2: diabetic control given normal saline

- Group 3: given $10 \mathrm{mg} / 100 \mathrm{~g}$ of VA

- Group 4: given 20mg/ $100 \mathrm{~g}$ of Metformin

- Group 5: given 20mg/ 100g Metformin and 10mg/ 100g VA

\section{Result}

\begin{tabular}{|l|l|l|l|l|}
\hline GROUP & $\begin{array}{l}\text { BEFORE ALLOXAN } \\
\text { FBS } \pm \text { SEM } \\
(\mathbf{m g} / \mathbf{d l})\end{array}$ & $\begin{array}{l}\text { AFTER ALLOXAN } \\
\text { FBS } \pm \text { SEM } \\
(\mathbf{m g} / \mathbf{d l})\end{array}$ & $\begin{array}{l}\text { AFTER N.SALINE/ VA/ } \\
\text { MET/ VA+MET } \\
\text { FBS } \pm \text { SEM } \\
\text { (mg/ dl) }\end{array}$ & $\begin{array}{l}\text { \% CHANGE } \\
\text { FBS }\end{array}$ \\
\hline 1 & $81 \pm 2.6$ & - & - & - \\
\hline 2 & $81 \pm 2.1$ & $293 \pm 6.5$ & $332 \pm 17.5$ & $13.3 \%$ \\
\hline 3 & $84 \pm 2.4$ & $304 \pm 3.8$ & $198 \pm 7.4$ & $-34.9 \%$ \\
\hline 4 & $89 \pm 2.5$ & $306 \pm 7.2$ & $190 \pm 4.2$ & $-37.9 \%$ \\
\hline 5 & $85 \pm 2.6$ & $310 \pm 7.4$ & $155 \pm 1.6$ & $-51.1 \%$ \\
\hline
\end{tabular}

Table 1: Fasting Blood Glucose of Wistar Albino Rats Before and After Induction of

Diabetes with Alloxan and after Treatment with Vernonia Amygdalina, Metformin and Combination of Both Vernonia Amygdalina with Metformin

Table1 shows the fasting blood glucose of Wister albino rats before induction of diabetes with alloxan. It can be seen that the fasting blood glucose of the rats were within the physiologic range and there was no significant difference between the groups are shown in table 2 (Levene test of homogeneity) .p > 0.05

\begin{tabular}{|c|c|c|c|c|}
\hline \multicolumn{5}{|c|}{ Test of Homogeneity of Variances } \\
\hline & $\begin{array}{c}\text { Levene } \\
\text { Statistic }\end{array}$ & df1 & df2 & Sig. \\
\hline After Alloxan & 2.437 & 3 & 16 & .102 \\
\hline Before Alloxan & .416 & 3 & 16 & .744 \\
\hline
\end{tabular}

Table 2 shows the Levene Homogeneity test of Variance. It shows that there was no significant difference between groups before inducing diabetes with alloxan and also, there was no significant difference between groups after the animals became diabetic by the administration of alloxan $(\mathrm{p}>0.05)$

\begin{tabular}{|c|c|c|c|c|c|}
\hline \multicolumn{7}{|c|}{ Analysis of Variance } \\
\hline & $\begin{array}{c}\text { Sum of } \\
\text { Squares }\end{array}$ & $\mathrm{df}$ & Mean Square & $\mathrm{F}$ & Sig. \\
\hline Between Groups & 166221.360 & 4 & 41555.340 & 120.026 & .000 \\
\hline Within Groups & 6924.400 & 20 & 346.220 & & \\
\hline Total & 173145.760 & 24 & & & \\
\hline
\end{tabular}

Table 3: Analysis of Variance after Treatment of Alloxan Induced Diabetic

Rats with Vernonia Amygdalinametformin/Va+Metformin

Table 3 showed the Analysis of Variance (ANOVA) after treatment of diabetic rats in group 2, 3, 4 and 5 with normal saline, $10 \mathrm{mg} / 100 \mathrm{~g} \mathrm{VA}, 20 \mathrm{mg} / 100 \mathrm{~g}$ metformin and $20 \mathrm{~g} / 100 \mathrm{~g}$ metformin $+10 \mathrm{mg} / 100 \mathrm{~g} \mathrm{~V}$. amygdalina. The result shows that there was a significant difference between diabetic control group and the group treated with either VA or metformin alone and as well as when combine $(\mathrm{P}<0.01)$.

Turkey's post Hoc analysis was used to determine where the significant difference was. From Turkey's post Hoc analysis, there was no significant difference between $10 \mathrm{mg} / 100 \mathrm{~g}$ of VA and $20 \mathrm{mg} / 100 \mathrm{~g}$ of metformin (P>0.05). There was a 
significant difference between the group treated with $10 \mathrm{mg} / 100 \mathrm{~g}$ of VA $+20 \mathrm{~g} / 100 \mathrm{~g}$ metformin and the group treated with monotherapy of either VA or metformin alone $(p<0.01)$.

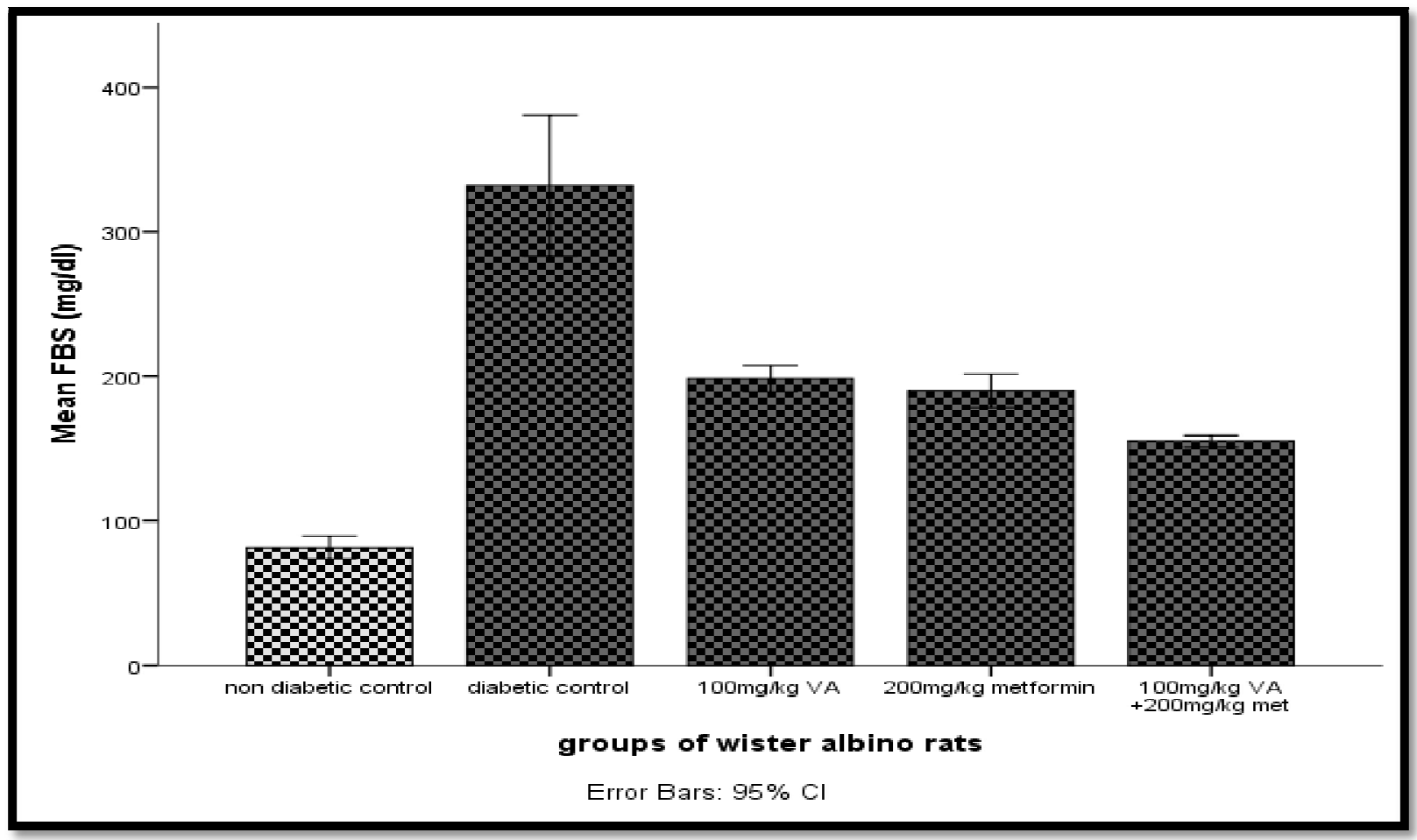

Figure 2

From fig 2, There was significant difference between the normoglycemic control group and diabetic control group ( $p>0.05$ ) which shows that alloxan significantly increase fasting blood glucose. There was also significant difference between Diabetic control group and group administered with $10 \mathrm{mg} / 100 \mathrm{~g} \mathrm{VA}, 20 \mathrm{mg} / 100 \mathrm{~g}$ metformin and the group given combined therapy of $10 \mathrm{mg} / 100 \mathrm{~g}$ VA with $20 \mathrm{mg} / 100 \mathrm{~g}$ metformin $(\mathrm{p}<0.01)$.

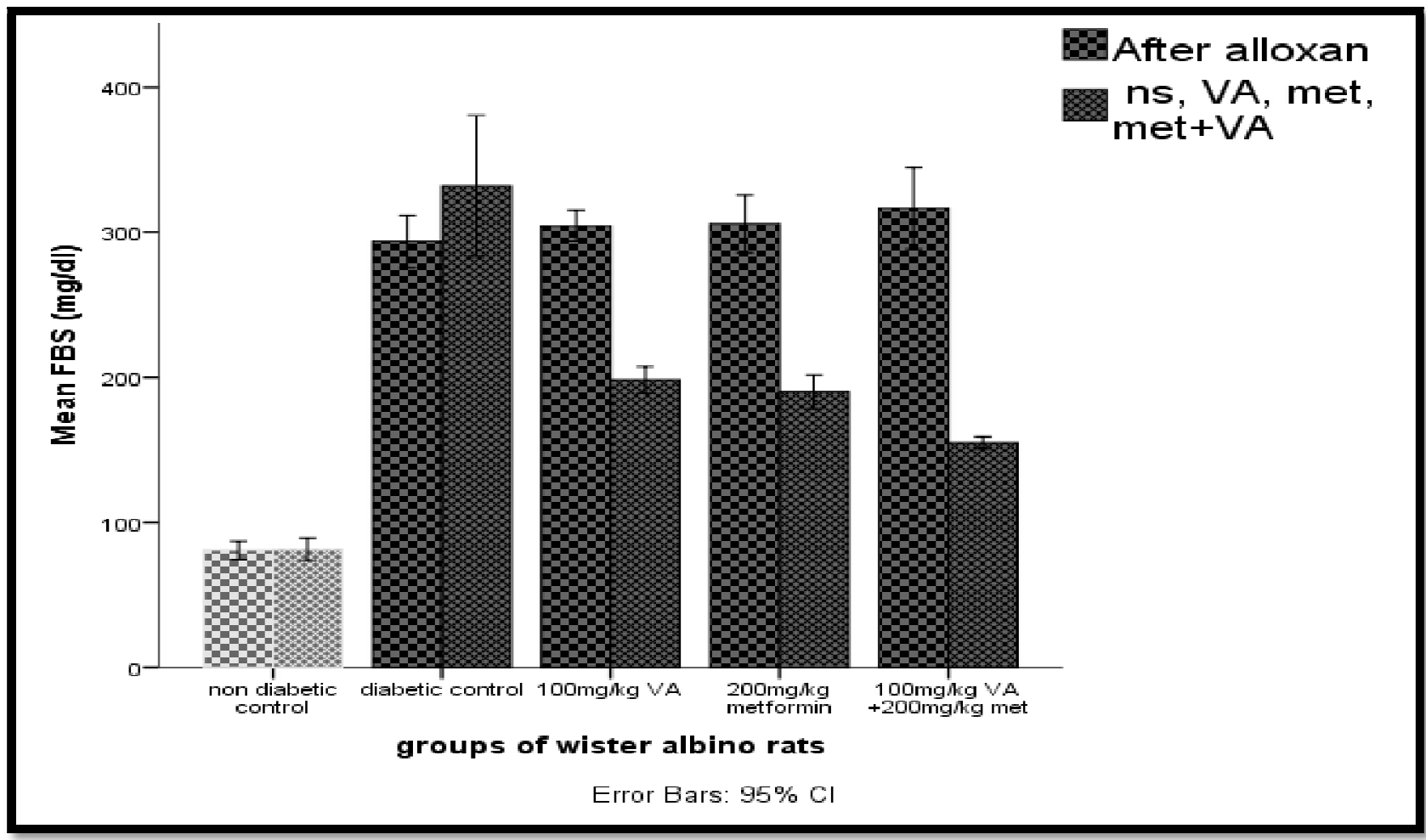

Figure 3 
Figure 3 shows the change in the mean of fasting blood glucose after administration of alloxan monohydrate and after administration of normal saline, $100 \mathrm{mg} / \mathrm{kg} \mathrm{VA}, 20 \mathrm{mg} / 100 \mathrm{~g}$ metformin, and $10 \mathrm{mg} / 100 \mathrm{~g}$ VA $+20 \mathrm{mg} / 100 \mathrm{~g}$ metformin. There was an increase in fasting blood glucose of the diabetic control given normal saline as diabetes worsen if appropriate hypoglycaemic agent is not used. There was a significant difference between fasting blood glucose after alloxan administration and after treating the various groups with $10 \mathrm{mg} / 100 \mathrm{~g} \mathrm{VA}, 20 \mathrm{mg} / 100 \mathrm{~g}$ metformin and $10 \mathrm{mg} / 100 \mathrm{~g}$ VA+20mg/ $100 \mathrm{~g}$ metformin $(\mathrm{p}<0.01)$.

\section{Discussion}

The result from this study shows that meformin significantly reduces the fasting blood glucose of alloxan induced diabetes in Wistar albino rats compared to the control $(p<0.01)$. VA also significantly reduced fasting blood glucose compared to the control $(\mathrm{p}<0.01)$. This agrees with the study of Akah et al., 2002. There was no significant difference in reduction of fasting blood glucose between metformin and Vernonia amygdalina ( $\mathrm{P}>0.05)$. The result also showed that co-administration of VA and metformin offered a reduction in fasting blood glucose that was significantly different from either metformin alone or VA alone $(\mathrm{p}<0.01)$. This agrees with the study of Adikwu et al.,2017., who documented the antihyperglycaemic effect of metformin and VA to be additive and that metformin and VA could act through the same mechanism. However, Onahinon et al.,2018 showed that one of the mechanism of action is to attenuate oxidative stress imposed on pancreatic cell by reactive oxygen species.

With the discovery of the role of liver in glucose metabolism by Claude Bernard in 1849, and also with the work of Gerty and Cori in 1947 on hepatic gluconeogenesis (Ahmed 2002), antihyperglycaemic agents with extra pancreatic mechanism of action have been developed. The most widely used antihyperglycaemic agent is metformin and it is currently recommended as the first line of therapy for all newly diagnosed type 2 diabetes mellitus patients (ADA, 2014). Metformin exerts its antihyperglycaemic effect primarily by suppression of hepatic gluconeogenesis. Zhou et al., 2001 demonstrated that this mechanism of action of metformin was through metformin -induced activation of 5' adenosine monophosphate -activated protein kinase (AMPK) which is associated with inhibition of hepatic glucose production. To a lesser extent, metformin reduces intestinal glucose absorption and also improves glucose uptake and utilization by peripheral tissue (Natali and Ferranni ,2006).

Vernonia amygdalinahave been shown to possess similar antihyperglycaemic effect (Akah et al., 2002; Onahinon et al.,2018). VA have been shown to reverse oxidative stress imposed on pancreatic beta cell by alloxan (Owolabi et al.,2011; Onahinon et al.,2018). The reduction of fasting blood glucose by VA in alloxan induced diabetes is as a result of several active constituents that have been reported to be present in VA extract (Mukwaya et al.,2016). These phytochemicals include Saponins, Phenols, Tannins, Flavonoids, Terpenes and Glycosides (Mukwaya et al.,2016). It has been shown that flavonoids possess remarkable hypoglycaemic effect (Cazarolli et al., 2008). This effect has been linked to its ability to impair glucose absorption and improve glucose tolerance (Cazarolli et al., 2008). Flavonoid have also been shown to be potent antioxidant agent that impair the generation of free radicals (El-Abhar, and Schaalan, 2014). It can therefore be concluded that VA shows a comparative similar efficacy with metformin.

\section{Recommendations}

Public health education about these findings is of utmost important to the general public. Train the trainer approach is recommended for dissemination of the useful findings in this research. People should be made aware that where metformin has been prescribed for the treatment of diabetes mellitus, the patient can equally benefit from the use of Vernonia amygdalina extracts especially when metformin is not readily available to the patients.

\section{References}

i. Adikwu Michael, Uzuegbu David, Okoye Theophine, Uzor Philip,Adibe Maxwell, Amadi Benson (2015). antidiabetic effect of combined aqueousleaf extract of vernonia amygdalina and bmetformin in rats. Journal of Basic and Clinical PharmacyVol-001, 197-202

ii. Ahmed Awad (2002). History of diabetes mellitus:Short Review.Saudi Med J 2002; Vol. 23 (4): 373-378

iii. Akah P.A., Okoli C.O and Nwafor,S.V. (2002) Phytotherapy in the Management of Diabetes Mellitus. Journal of Natural Remedies, 2, 1-10

iv. American Diabetes Association (2014). Standards of medical care in diabetes Diabetes Care 37 (Suppl 1), S14-S80

v. Cazarolli, L.H., Zanatta, L., Alberton, E.H., Figueiredo, M.S., Folador, P., Damazio, R.G., Pizzolati, M.G. and Silva, F.R. (2008) Flavonoids: Cellular and Molecular Mechanism of Action in Glucose Homeostasis. Mini-Reviews in Medicinal Chemistry, 8, 1032-1038.

vi. Defronzo RA (2009). Banting Lecture. From the triumvirate to the ominous octet: a new paradigm for the treatment of type 2 diabetes mellitus. Diabetes.58(4):773-95

vii. El-Abhar, H.S. and Schaalan, M. (2014) Phytotherapy in Diabetes: Review on Potential Mechanistic Perspectives and relative hyperglucagonemia in the minipig. Diabetes. 50:12.

viii. International Diabetes Federation (IDF) (2013). One Adult in ten will have Diabetes by 2030. [Online] Available http:/ / www.idf.org/ diabetesatlas. 
ix. Kjems LL, Kirby BM, Welsh EM, Veldhuis JD, Straume M, McIntyre SS, Yang D, Lefebvre P, Butler PC. (2001) Decrease in beta-cell mass leads to impaired pulsatile insulin secretion, reduced postprandial hepatic insulin clearance World Journal of Diabetes, 5, 176-197

x. Mukwaya Z, Engoru T, Kainza EJ, Inyani JK, Buligwanga S, Munanura EI, Kalidi R, Mugisha M, Adome , Anyama N, Kamba P, Kaggwa B (2016). Efficacy Of A Syrup Formulated From Combined Extracts Of Vernonia Amygdalina And Musa Paradisiaca For The Management Of Type 2 Diabetes. African Journal of Pharmaceutical Research \& Development Vol. 8 No. 2; pp. 71-80

xi. Natali A. and Ferrannini E (2006). Effects of metformin and thiazolidinediones on suppression of hepatic glucose production and stimulation of glucose uptake in type 2 diabetes: a systematic review. Diabetologia 49,434-441.

xii. Onahinon C., Eru E., Ibu J (2018). Effect of Vernonia amygdalina Found in Alloxan Induced diabetes. International Journal of Research and Development: Vol 7, 154-159

xiii. Osigwe C. , Akah P. , Nworu C. , Okoye, T. and Tchimene M. (2015). Antihyperglycemic Studies on the Leaf Extract and Active Fractions of Newbouldia laevis (Bignoniaceae). Pharmacology \& Pharmacy, 6, 518-532

xiv. Owolabi M., Jaja S., Olatunji., OJa., Oyekanmi O., Adepoju S (2011).Attenuation of Oxidative Damage in Alloxan Induced Diabetic Rabbits Following Administration of the Extract of the Leaves of Vernonia amygdalina.Free Radicals and Antioxidants Vol 1, Issue 3, 94-101

xv. Tanaka T, Tong HH, Xu Y, Ishimaru K, Nonaka G, Nishioka (1992). Tannins and related compounds: Isolation and characterization of three new ellagitannins, lagerstannins A, B and C, having a gluconic acid core, from Lagerstroemia speciosa (L.) Chem and Pharmaceu Bull Tokyo. 1992;40(11):2975-2980

xvi. Tattersall RB (2009). Diabetes The biography. Oxford University Press

xvii. Zhou G., Myers R., Li Y., Chen Y., Shen X., Fenyk-Melody J., Wu M.,Ventre J., Doebber T., Fujii N (2001). Role of AMPactivated proteinkinase in mechanism of metformin action. J. Clin. Invest. 108, 1167-1174. 